\title{
Dynamics and Logics of Civil War
}

\author{
Lars-Erik Cederman and Manuel Vogt \\ ETH Zürich
}

May 23, 2017

Since the early 2000s, the literature on civil war has experienced a tremendous boom that stands in stark contrast to the past century. While civil war quickly overtook interstate war as the most important type of armed conflict in the postWWII period, conflict researchers have been relatively slow to adapt to this trend. Related topics such as "revolutions" and "ethnic conflict" enjoyed their respective surges of scholarly attention in the 1970s and 1990s, but most scholarship using "civil war" as a conceptual category appeared during the past one and a half decades. Clearly, centuries of warfare, including two world wars, together with the threat of superpower confrontation during the Cold War cast a long shadow over the field.

After this slow start, however, the field of civil war studies has evolved into one of the most vibrant literatures in political science and the related social sciences. Civil war studies have contributed to integrating subfields such as international relations and comparative politics, and stimulated methodological progress. Based on data drawn from the Web of Science, Figure 1 shows how the publication trend of articles covering civil war in political science, economics, and sociology slowly increases after the end of the Cold War and then takes off in the early 2000s after decades of very low publication activity. The Journal of 
Conflict Resolution has played a leading role in this impressive development. According to the Web of Science, the JCR published three of the ten most cited articles on civil war, more than any other field journal. Among the 20 most cited articles, the journal counts as many as eight.

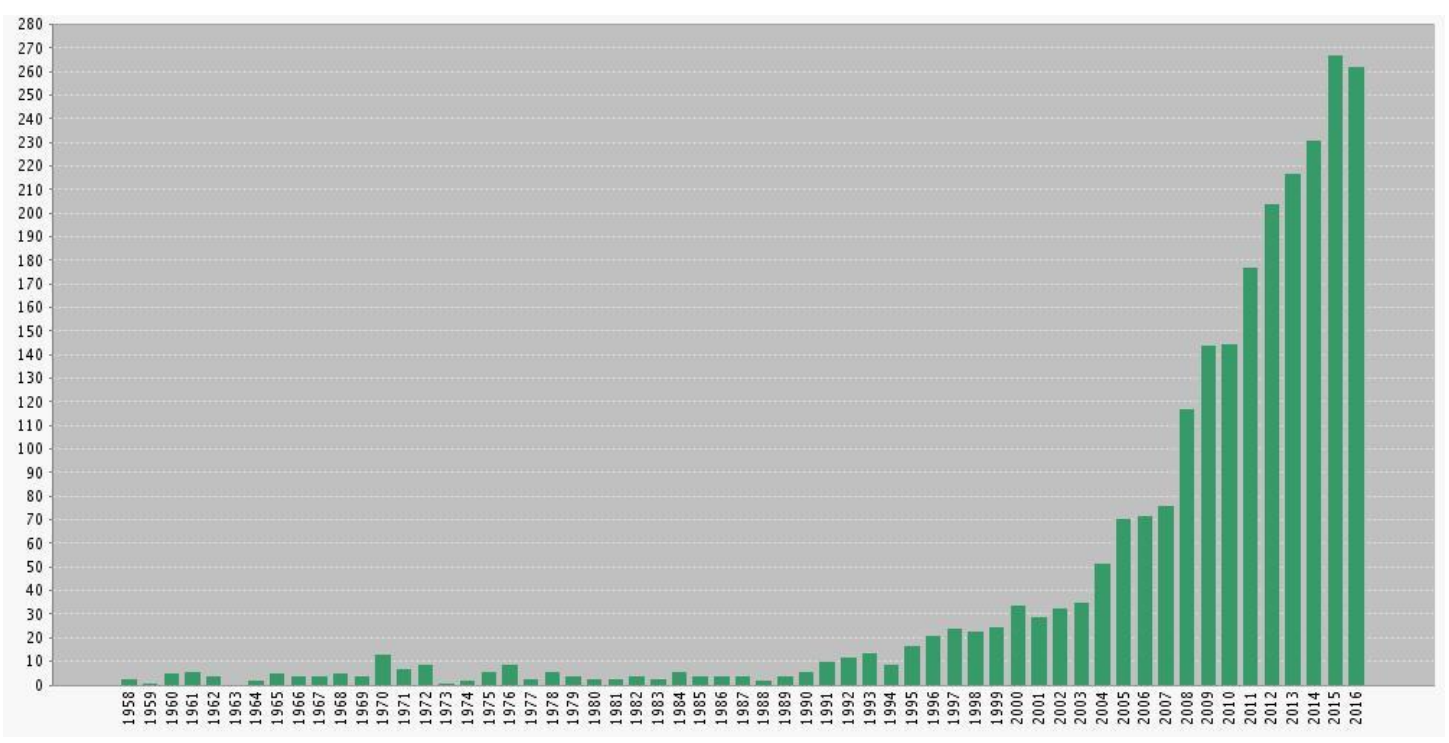

Figure 1. Number of "civil war" articles published in political science, economics and sociology journals. Source: Web of Science.

The current review will focus primarily on the most recent period of civil war research. After an early review by Sambanis (2002), previous article-based efforts to survey the literature by Kalyvas (2007) and Blattman and Miguel (2010) date back almost a decade. Since important advances have been made in the field since then, we believe that it is high time to take stock of the literature. We focus on contributions to civil-war studies in political science, with some coverage of economics and sociology as well. 
Civil war can be defined as armed combat within a sovereign state between an incumbent government and a non-state challenger that claims full or partial sovereignty over the territory of the state. In other words, civil war always concerns an incompatibility in terms of political control. ${ }^{1}$ Following the conventions of the Uppsala Conflict Data Program (UCDP) (Gleditsch et al. 2002, 619), we speak of governmental civil wars if the main objective of the challenger is full governmental control of the state. If the main goal of the rebels is to secede or to increase their influence over a part of the territory, the conflict can be classified as a territorial civil war. With a view to "technologies of rebellion," Balcells and Kalyvas (2014) distinguish between irregular conflicts, defined as guerilla conflicts between conventional state armies and lightly armed rebels, and conventional wars involving heavily armed opponents and clear frontlines.

Based on this definition, it is clear that civil war needs to be distinguished from civilian victimization, such as terrorism, state terror, mass killings, and genocide, although these types of political violence may occur during civil wars (Valentino 2014). Furthermore, "non-state violence," such as riots and communal violence have to be excluded from the definition since in such cases the state does not participate directly in combat. In particular, the somewhat imprecise concept of "ethnic conflict" is different from ethnic civil wars since it also includes ethnic one-sided violence and ethnic riots.

Having defined our main concepts, we can now turn to the organization of this review. By way of introducing a measure of substantive structure, we discern three explanatory logics in the civil-war literature that correspond roughly to 
explanations highlighting grievance, greed, and opportunities. Grievance-based accounts view internal conflict as a reaction to socio-economic and/or political injustice. In contrast, explanations centering on greed make sense of civil war in terms of individuals' desire to maximize their profits, primarily in a narrowly materialist sense. Arguing that motives are less important, a third logic seeks the causes of civil war in the opportunities that enable actors to engage in violent mobilization. Obviously, these are merely ideal-typical explanatory patterns that often blend into each other. Especially the greed and opportunities logics often appear in close association. In this review, we will argue that one of the most important tasks for future civil-war research will be to further break down the artificial barriers that stand in the way of more subtle and complex "blends."

In order to further structure our exposition of the literature, the following sections correspond to the main phases of civil war processes. Thus, in the next section, we review the literature on the outbreak of civil war, before discussing the dynamics during civil wars and civil-war termination. We conclude the phase-based survey with a review of the literature that covers post-war phenomena. The article ends with a discussion of open research questions. 


\section{Civil-war Initiation}

Echoing classic research on the "causes of war" that has dominated the study of interstate warfare (Levy 1989), the civil war literature has primarily attempted to address the question of what causes armed internal conflict in the first place. The contemporary debate has intellectual roots that date back to the 1960 s and 1970s. Responding to conservative and normative conceptions of civil war as irrational outbursts of mass violence, Gurr (1970) introduced a class of explanations that corresponds to the aforementioned grievance logic. According to Gurr's "relative deprivation theory," the failure to achieve aspired goals triggers frustration that makes violence more likely. However, this primarily psychological and individualist perspective attracted criticism from scholars who argued that grievances are less important than the structural environment and political processes that determine rebels' opportunities, as well as their organization and resources (Tilly 1978). Reflecting the ideological confrontation between the super powers, civil wars were typically studied as "peasant rebellions" (Scott 1976) or "social revolutions" (Skocpol 1979).

Following the end of the Cold War, large-scale violence in Yugoslavia and Rwanda triggered a new wave of scholarship under the heading of ethnic conflict. While much of the early research stressed an opportunity-driven logic that explained violence as a reaction to a security dilemma resulting from state collapse (e.g., Posen 1993), others were less reluctant to rely on motivationbased accounts highlighting inter-ethnic hatred (e.g., Kaplan 1994) or even clashes between civilizations defined as world religions (Huntington 1996). 
Pursuing a more systematic empirical strategy, Gurr and his collaborators launched a major data collection effort on "Minorities at Risk" (MAR) that allowed him to broaden his theoretical approach to encompass both grievances and opportunity-related logics (see, e.g., Gurr and Scarritt 1989).

Focusing on "ethnic conflict" in the 1990s, conflict researchers had yet to rediscover the importance of civil war as a research topic. In fact, it was a team of economists at the World Bank led by Paul Collier that made the main breakthrough. In a series of influential papers, many of which were co-authored with Anke Hoeffler, Collier introduced a new class of explanations based on greed, which was explicitly pitted against grievances. In a much-cited article, Collier and Hoffler (2004) summarized their argument under the title "Greed vs. Grievance in Civil War." Echoing arguments made by Tilly and others in the 1970s, these scholars argued that grievances are immaterial because they are ubiquitous and therefore cannot explain the outbreak of rare events such as civil wars. Instead, grievances are merely used as an ideological smokescreen by greedy rebel leaders who, rather than being swayed by political ideas, are assumed to carefully calculate the costs and benefits of resorting to arms. According to this microeconomic framework, civil wars can be expected to break out where the opportunity costs of fighting are low because of poverty, and where wartime gains stemming from looting of natural resources lead to personal enrichment and financing of rebels' combat activities.

In parallel to Collier and Hoeffler's elaboration of their mostly greed-driven, microeconomic perspective, Fearon and Laitin (2003) introduced what has 
become the most influential explanation of civil-war onset in the literature. Stressing an opportunity logic that explains how insurgent violence is more likely to erupt in weak states than in those with stable and resourceful governments, the most-cited article on civil war shifts the attention away from rebel motivations to political and institutional factors. In particular, this applies to the role of natural resources, although deviating from Collier and Hoeffler's emphasis on lootability and rebel finance. Inspired by economic theories on the "resource curse," the article applies this concept to the functioning of the state, in order to explain why oil extraction leads to bad governance and state weakness. Rather than investing in tax collection and public good provision, resource abundant governments can take the shortcut of rent seeking. But this also means that their control of the state's territory, especially in peripheral regions with inaccessible terrain, is weak, making uninformed and brutal counterinsurgency fighting more likely once insurgencies occur.

While Fearon and Laitin (2003) use GDP per capita as a proxy to test the stateweakness argument, subsequent studies have confirmed the original claim by measuring bureaucratic state capacity more directly (Hendrix 2010; Fearon 2011). In contrast to their arguments about state reach, their conjecture relating to a governmental "resource curse" has fared less well in the recent literature. In particular, geographically disaggregated studies based on more precise data show that the oil-conflict link is located at the local level rather than running through the government (Lujala 2009). Furthermore, the original argument fails to take the obvious endogeneity of oil extraction into account (Ross 2015), and 
also overlooks that petroleum revenues may actually reduce conflict by helping governments bribe or suppress the opposition (Paine 2016).

In a comprehensive econometric survey, Hegre and Sambanis (2006) confirm that many of the factors that are compatible with the greed and opportunity logics appear to be the most robustly related to civil-war onset, with the partial exception of the pacifying effect exerted by democracy. In an important precursor to the weak state paradigm, Hegre et al. (2001) find that semidemocracies are more prone to civil violence than stable autocracies and democracies. Although this account refers both to the grievance-reducing impact of democracy and to the opportunities for violence present in institutionally weak "anocracies," it is the latter interpretation that has become the most influential (see, e.g., Fearon and Laitin 2003). However, because of measurement problems relating to the Polity index, this curvilinear effect of democracy does not appear to be robust (Vreeland 2008).

While the greed logic did not entirely disappear from the theoretical agenda, especially in economics, it is Fearon and Laitin's (2003) "weak state" interpretation that has become the dominant explanatory paradigm in the civil war literature. ${ }^{2}$ Much of what has been written on civil war since the early 2000s can be seen as reactions to this paradigm. Unsurprisingly, the categorical dismissal of grievances as causes of war triggered criticism, especially since it seemed to contradict many qualitative accounts of how protest against injustice and inequality caused internal conflict. Rather than dismissing this logic per se, then, some researchers argued that the absence of evidence could be an artifact 
of imperfect proxies (Sambanis 2004b; Blattman and Miguel 2010). In particular, the attempt to capture grievances with individualist demographic indicators, such as ethno-linguistic fractionalization or the Gini coefficient, loses sight of the fact that many civil wars are fought between ethnic groups (Cramer 2003; Cederman and Girardin 2007). According to theories of nationalism, conflictinducing tensions tend to arise where state and national borders do not coincide, especially where ethno-nationalist groups are exposed to "alien rule" (Gellner 1983). In this sense, "horizontal inequality" between entire groups may be more consequential than inequality measured along individual and household lines (Stewart 2008; see also Østby 2008). To some extent, Gurr's (1993) MAR data capture group inequality and discriminatory state policies, but the failure to sample all ethnic groups, including many of the dominant ones, makes it difficult to draw safe inferences based on this dataset (Fearon 2003; though see Hug 2013).

As a response to these difficulties, the Ethnic Power Relations (EPR) dataset documents all politically relevant ethnic groups and their power access since WWII. Based on these data, Cederman, Wimmer and Min (2010) show that excluded ethnic groups, especially those that suffered status reversals, are overrepresented in conflict statistics. They explain this finding primarily from a grievances perspective, while also stressing opportunity-related factors, such as group size. Using EPR's geocoded data on ethnic settlement areas, Cederman, Weidmann and Gleditsch (2011) extend the study of political exclusion to economic inequality, in order to show that ethnic groups that are poorer and richer than the country's average income are more likely to stage rebellion. 
Arguing against the conventional critique of grievances, including the ubiquity argument cited above, Cederman, Gleditsch and Buhaug (2013) postulate that both political and economic inequalities spur mass grievances, which in turn increase the likelihood of mobilization and ultimately civil-war outbreak. ${ }^{3}$

These group-based investigations can also be seen as a part of a general trend toward more disaggregated studies of civil-war onset, a trend that has become even more pronounced in studies of violence during civil war. In order to circumvent problems of ecological inference resulting from over-aggregation to the country level, more recent studies code and analyze large cross-national samples of sub-national actors, such as rebel organizations, self-determination movements, or other types of political organizations (Cunningham, Gleditsch, and Salehyan's 2009; Cunningham 2013; Wucherpfennig et al. 2012). Using new data on religious and linguistic identities within ethnic groups, Bormann, Cederman and Vogt (2017) find that ethno-linguistic between-group divisions are more likely to produce civil violence than ethno-religious ones. Often, geographic information systems are used to extract information about subnational geographic factors based on grid-cell observations (Tollefsen and Buhaug 2015).

Another important deviation from the standard cross-national "work horses" treats civil war in an "open-polity" setting (Gleditsch 2007). Rather than assuming that civil war is caused by merely domestic factors, this research investigates to what extent transnational mechanisms, relating to refugees (Salehyan and Gleditsch 2006), ethnic kin (e.g., Saideman and Jenne 2009; 
Cederman et al. 2013), the demonstration effects of grievance-based conflicts caused by ethnic exclusion (Metternich, Minhas, and Ward forthcoming), or other types of diffusion effects, may trigger civil-war onset. Generally, the results confirm that civil war cannot be reduced to a "closed-polity" model and that both (ethnic) grievances and opportunities contain an important transnational dimension (for a recent review, see Forsberg 2016).

\section{Violence during Civil War}

As we have seen, the dominant paradigm in civil-war studies that emerged in the early 2000s applies statistical models to cross-national data while postulating that the roots of conflict can be found in state weakness. Beyond giving rise to disaggregated onset analyses, this research program also inspired a more radical turn to micro-level methods applied to within-conflict dynamics in specific cases. In contrast to the aforementioned quantitative meso-level studies of civil war, the "micro-dynamic" literature relies on a broad set of innovative methods including case studies, archival data, and anthropological methods, often in connection with field research. Putting causal identification on a more solid basis than is possible with over-aggregated data and loose proxies, these studies echo a more general tendency in favor of experimental methods and careful tracing of processes to improve internal validity by sacrificing some external validity.

More than any other work, Kalyvas (2006) laid the groundwork for the new micro-theoretic agenda by arguing that civil war research had too long focused 
on identifying the structural causes of civil-war initiation at the expense of local war-time dynamics. In particular, the main explanatory challenge shifts from explaining triggers of entire civil wars to accounting for wartime civilian victimization. Rather than seeking the roots in overarching "cleavages," then, this perspective views violence as a "deeply endogenous" phenomenon composed by a myriad of private, mostly opportunistic motives unleashed by the war itself, including individual score settling and personal vendettas. Using the Greek civil war as a starting point, the core of his theory expects civilian victimization to be most pronounced in areas where neither side of the civil war enjoys full territorial control or civilian support.

Most wartime violence targeting civilians is perpetrated by governments (Valentino 2014). In particular, governments facing guerrilla insurgencies are likely to target civilians in order to root out the rebels' popular support (Valentino, Huth, and Balch-Lindsay 2004). Often, the violence is "outsourced" to pro-government militias (Carey and Mitchell 2017). With respect to violence against civilians committed by rebel organizations, one of the most prominent explanations was advanced by Weinstein (2007). Transferring the logic of the resource curse from governments to rebel organizations, he argues that rebel organizations that are well endowed in terms of natural resources attract members who are interested in private material gain and, thus, are more likely to abuse civilians than those organizations that depend on civilian cooperation (see also Humphreys and Weinstein 2006). 
In recent years, the micro-dynamic research agenda has expanded into a fertile research program focusing also on how rebel organizations and militias mobilize fighters and organize themselves. Stressing opportunistic side-shifting by civilians caught up between both sides in civil wars, Kalyvas (2006) anticipates that mobilization will vary both in time and space depending on the flow of combat. Faced with high levels of indiscriminate violence, many individuals may prefer the relative safety of rebel organizations rather than risk being killed as civilians (Kalyvas and Kocher 2007). Instead of being a function of the overarching cleavage, individual loyalties are assumed to follow local and momentary circumstances. Using micro-level data from post-war Sierra Leone, Humphreys and Weinstein (2008) take a broader perspective on individual motivations that highlights socio-economic deprivation and social pressure, in addition to security concerns, while rejecting the relevance of political grievances.

Despite the predominant focus on opportunities and constraints in the microlevel literature, some studies emphasize the importance of individuals' grievances and ideological motivations. In a pioneering article that explains how rebels are able to overcome severe collective action problems, for instance, Gates (2002) introduces a game-theoretic framework that shows how the "microfoundations of rebellion" depend on geography, ethnicity, and ideology. Based on anthropological field studies in El Salvador that highlight the grievance logic in full action, Wood (2003) argues that the "pleasure of agency" animated farm workers to resist severe socio-economic injustices despite massive violent repression by landowners. Ugarriza and Craig (2013) find that even in an 
allegedly economically motivated conflict, such as the Colombian civil war, ideology plays an important role in the internal dynamics of armed groups.

Other alternatives and extensions to Kalyvas' endogenous, combat-driven account of both mobilization and civilian targeting can be found in studies that highlight the relevance of pre-war structures. According to Weidmann (2011), ethnic one-sided violence in Bosnia-Herzegovina in the early 1990s cannot be explained merely in terms of local ethnic polarization, but followed a distinctly “top-down” logic of ethnic cleansing. Relatedly, Fjelde and Hultman (2014) find that warring parties in African ethnic civil wars tend to use civilian targeting in order to weaken their enemies' ethnic core constituencies. In her study of the Spanish civil war, Balcells (2017) shows that in conventional civil wars, identification and civilian victimization can be driven by ideological commitments antedating the outbreak of the armed conflict. Finally, Staniland (2014) explains variations in terms of rebel organization's longevity and robustness by tracing their roots in "prewar politicized social networks" that affect their cohesion and combat effectiveness.

Shifting the focus from the causes to the consequences of civilian victimization, often in counterinsurgency campaigns, some studies explain how one-sided violence can account for variations in the intensity of fighting, including escalation and de-escalation. Most studies appear to support Kalyvas' initial conjecture that indiscriminate violence is counter-effective. Using evidence from the Vietnam War, Kocher, Pepinsky and Kalyvas (2011) find that those villages that were hit by US airstrikes were more likely to come under the influence of 
Vietcong. Schutte (forthcoming) shows that in the Afghan civil war, civilians reacted to indiscriminate violence by colluding with the perpetrators' adversary, although in a relatively safe spatiotemporal distance from the trigger event. In an exception from the dominant view, Lyall (2009) argues that the use of indiscriminate violence by Russian artillery helped curb rebel resistance in Chechnya. Moreover, focusing on civilian victimization by rebel groups, Thomas (2014) finds that the use of terror attacks during civil wars may actually help rebel groups gain concessions from state governments.

In sum, the micro-theoretic turn has enriched the study of civil war by offering a much more fine-grained picture of underlying mechanisms and dynamics than onset studies. While the literature can be seen as a critical reaction to the dominance of the state weakness paradigm described in the previous section, Kalyvas' initial formulation also weakens the link to political grievances at the macro level in favor of an opportunity-driven focus on combat technologies. However, by highlighting the crucial role played by the path-dependence of prewar identities and structures, the more recent literature at least partly questions this radical detachment of micro-level patterns from overall, macrolevel cleavages (see, e.g., Balcells 2017). While acknowledging that civil wars are immensely complex processes, more recent research introduces a broader spectrum of explanatory logics that includes not merely individual greed and private grudges, but also ideologically committed individuals who are fighting to overcome repression and injustice (Gutiérrez Sanín and Wood 2014). 


\section{Civil War Termination}

Beyond asking how civil wars start and evolve, conflict researchers also investigate when and how they end. Indeed, ongoing conflicts contribute at least as much to conflict incidence as new onsets do. Conceiving of conflict continuation as repeated decisions to fight, most studies rely on arguments that are directly derived from the three main logics governing onset, although there are some surprising nuances. In many ways, the study by Collier, Hoeffler, and Söderbom (2004) reflects Collier and Hoeffler's (2004) greed-based view of civil war as a lucrative business that occurs when rebellion is financially feasible and rebels can secure themselves high rents from conflict. Their study finds preliminary evidence that wartime increases in commodity prices make conflicts in export-dependent countries last longer.

Proposing an inductive approach to conflict duration, Fearon's (2004) offers some interesting contrasts to Fearon and Laitin's (2003) opportunity-driven onset account. His analysis identifies two scenarios that are associated with particularly long-lasting conflicts. In the first scenario, rebel groups receive funding from contraband, such as opium, diamonds, or coca. The second scenario corresponds to Weiner's (1978) concept of "sons-of-the-soil" conflicts that pit a peripheral ethnic minority against a dominant ethnic group that encroaches on the minority's territory through migration of its members. While contraband activities may be facilitated by state weakness, the arguments about wartime profits and rebel financing come closer to the greed-based logic. ${ }^{4}$ Moreover, the sons-of-the-soil scenario at least implicitly acknowledges the influence of ethnic 
grievances. To explain these inductively derived empirical patterns, Fearon develops a bargaining model that shows how commitment problems block negotiated conflict resolution rather than uncertainty.

Disaggregating conflicts into dyads between the state and rebel organizations, Cunningham, Gleditsch, and Salehyan's (2009) account of conflict duration and outcome also incorporates elements of both the opportunities and grievances logics. Their results indicate that civil wars tend to endure when rebels control territory in the periphery that allows them to escape government repression and when they are prevented from using non-violent political means to advance their demands. In contrast, relying mostly on an opportunities-driven logic, Buhaug, Gates, and Lujala (2009) theorize how the distance to the state capital, terrain, and rebel financing through natural resources influence the relative military capacities of the rebels and the government.

The grievances logic, complemented with a bargaining perspective on war termination, is dominant in Wucherpfennig et al. (2012) who argue that ethnopolitical exclusion leads to longer wars (see also Cederman, Gleditsch, and Buhaug 2013, Ch. 8). Such policies increase group solidarity and mobilization on the part of the aggrieved ethnic groups that rebel against the state. The findings suggest that the sons-of-the-soil type of civil war emphasized by Fearon (2004) is a special case of ethno-political exclusion.

Whereas these arguments of conflict duration are closely connected to theories of onset, Balcells and Kalyvas (2014) claim that the duration and outcome of civil 
wars are endogenous to warfare itself. Drawing on the micro-level literature, they argue that "technologies of rebellion" are the decisive variable. They find that irregular conflicts last longer than conventional wars and tend to be won by the government whereas conventional wars are more likely to end in rebel victories. $^{5}$

Other factors that are endogenous to conflict include the number of parties involved and external intervention. David Cunningham (2006) and Kathleen Gallagher Cunningham (2013) find that the former increases conflict duration by raising uncertainty and exacerbating commitment problems. There is a rich empirical literature that examines the consequences of third-party intervention, focusing, for the most part, on peacekeeping missions. ${ }^{6}$ The interest in such interventions reflects the rationalist expectation, advanced, in particular, by Walter (1997), that without outside intervention, civil wars are inherently difficult to settle because the parties are unable to credibly commit to the negotiated terms.

Overall, the "when" has received much more attention than the "how" in studies of conflict termination. Thus, a more comprehensive examination of civil war outcomes constitutes a potentially fruitful avenue for future research. Bargaining theories of war play a prominent role in the literature on conflict duration, especially in opportunities-based explanations, although they are potentially compatible with all three logics that have dominated research on civil war onset. 


\section{The Aftermath of Civil War}

War-torn countries face enormous challenges in restoring order and security, rebuilding the economy, reintegrating combatants, and healing the wounds of violence. According to Collier et al. (2003), the dire socio-economic consequences of civil violence prepare the ground for renewed conflict by locking countries into a "conflict trap." Moreover, the adverse economic consequences of civil wars tend to spill beyond the conflict states, having an important negative impact on economic growth in neighboring countries (Murdoch and Sandler 2002).

Since conflict recurrence constitutes the most immediate threat, this issue has been at the core of the post-conflict literature. Consequently, the scholarly debate has been structured according to the logics used in onset studies. First, grievances-based approaches emphasize the need to reduce injustices through governmental concessions, for example in the form of democratization, power sharing, or minority rights. Most prominently, Gurr (2000) detected a trend towards more accommodative state policies since the mid-1990s and predicted that these policies would lead to a significant decline in intra-state warfare.

Analyzing the political, territorial, military, and economic power-sharing provisions in peace agreements, Hartzell and Hoddie (2003) find that postconflict peace tends to be stable in proportion to how many of these dimensions are included in such agreements. They conclude that only extensive and multifaceted power sharing provides the former warring parties with the 
necessary sense of security to engage in lasting cooperation. This conclusion dovetails with arguments that detailed agreements with strong power-sharing provisions may alleviate commitment problems (Walter 1997, 360-2) and information asymmetries (Mattes and Savun 2010) in post-conflict environments. For instance, Cederman et al. (2015) find that while territorial power sharing by itself decreases the risk of ethnic conflict onset, it is not enough to prevent conflict recurrence. Hence, in post-conflict situations, stable peace may require territorial autonomy to be buttressed with governmental power sharing at the center (see also McGarry and O'Leary 2009).

A number of studies have examined the effects of more specific accommodative policies designed to reduce inequality and grievances. For instance, analyzing the consequences of land reform for the intensity of guerrilla activity in Colombia, Albertus and Kaplan (2013) find that large-scale land reforms risk being blocked by powerful stakeholders, but if enacted they often have a pacifying effect in countries characterized by high land inequality. In terms of military power sharing, a recent study of post-conflict Burundi by Samii (2013) suggests that policies (such as quotas) designed to foster ethnic inclusion in the military may help transcend ethnic conflict. This finding confirms more general arguments about how ethnic balancing in the armies helps pacify ethnically divided countries (see, e.g., Wilkinson 2015).

Finally, a vast literature has studied the consequences of post-conflict democratization. Diamond (2006) endorses democratic elections as a means to legitimize post-conflict governments and provide former rebels with a peaceful 
mechanism to influence politics. However, in the context of weak institutions, democratization may exacerbate existing social tensions, thus making conflict recurrence more likely (see, e.g., Paris 2004). Indeed, competitive elections have been found to undermine post-conflict peace building, especially if held too soon after the end of violence (Brancati and Snyder 2013).

In contrast, advocates of the greed-as-motivation logic highlight economic development in their explanations. From this perspective, conflict recurrence is least likely if a return to fighting becomes financially unattractive for individuals. Concretely, post-conflict pacification calls for quick macro-economic recovery that creates employment and, thus, increases the opportunity costs for potential rebels, especially young males. Indeed, Collier, Hoeffler, and Söderbom (2008) produce evidence of a negative effect of per-capita income and income growth on the risk of conflict recurrence. ${ }^{7}$

In addition to ordinary fighters' material disincentives, Collier, Hoeffler, and Söderbom (2004) emphasize the importance of curtailing rebel funding, for example by impeding the looting and contraband of natural resources. Moreover, if civil wars are the consequences of greedy warlords (Reno 1998), one would expect that lasting peace in post-conflict countries can only be achieved through targeted "politics of the belly" (Bayart 1993) that bribes rebel leaders into compliance. Providing material and political incentives for rebel leaders has become common practice in civil war settlements, especially in Sub-Saharan Africa, but the corresponding demonstration effects may also legitimize violent behavior (Tull and Mehler 2005). 
The advocates of the opportunities approach exhibit a similar skepticism toward pacification through political concessions. If renewed rebellion is primarily a function of opportunities, power sharing should be inherently difficult to achieve and maintain because of severe commitment problems (Fearon 2004; Walter 1997). The former warring parties will typically be unable to credibly commit to permanently refrain from violence, especially if governments renege on their power-sharing promises, and if power sharing provides rivals with the means to strike from within the state apparatus (Roessler 2011) or from autonomous institutions (Roeder 2009).

Another implication that can be derived from the opportunity logic, especially from Fearon and Laitin (2003), is that post-conflict interventions should focus on strengthening state capacity rather than reducing grievances through governmental concessions (Mack 2002, 522). ${ }^{8}$ Indeed, a number of scholars have argued that territorial autonomy arrangements fragment state power while empowering regional challengers (Bunce and Watts 2005; Roeder 2009). Yet, the problem with these arguments is that they do not take into account why territorial power sharing, such as ethnic federalism, is enacted in the first place. Considering these usually delicate ethno-political conditions, the track record of autonomy regimes looks much more positive (McGarry and O'Leary 2009; Cederman et al. 2015). In contrast, the usefulness of partition as a tool of conflict resolution has been effectively challenged in the literature although it may serve as a last resort (see, e.g., Sambanis and Schulhofer-Wohl 2009). 
Beyond the issue of conflict recurrence, an emerging literature addresses the legacies of civil warfare. At the macro level, such studies focus on war's economic consequences for the affected countries, while micro-level research analyzes a range of socio-economic and political outcomes as reported by ex-combatants and victims of violence. While the immediate economic costs of civil war are undisputable, there is growing evidence that economic recovery does occur in a relatively speedy manner (Chen, Loayza, and Reynal-Querol 2008; Miguel and Roland 2011). If the aforementioned "conflict trap" is not primarily a function of sustained economic depression, political interventions might after all be crucial to avoid conflict recurrence (e.g., Walter 2015).

At the individual level, civil wars expose participants and victims to long-term harm in terms of educational achievement, employment, and physical and psychological health (Blattman and Annan 2010; Canetti-Nisim et al. 2009). Yet, war experiences also may increase participants' and victims' political and community participation, and many of them report post-trauma personal growth (Bellows and Miguel 2009; Blattman 2009). In a recent summary of this literature, Bauer et al. (2016) conclude that while war tends to foster in-group altruism, in particular, this does not seem to extend to out-groups. Furthermore, the staggering rise in violent crime and homicide rates in Latin and Central America has led scholars to analyze the link between individual conflict experiences and post-war criminal behavior (e.g., Kaplan and Nussio forthcoming). Overall, however, the literature has produced relatively little systematic knowledge about individuals' post-conflict grievances, attitudes towards reconciliation, and, in particular, how such individual-level 
consequences aggregate up to collective outcomes (though see Grossman, Manekin, and Miodownik 2015). Thus, Blattman and Miguel's $(2010,42)$ conclusion that " $[t]$ he social and institutional legacies of conflict are arguably the most important but least understood of all war impacts" still remains true today.

\section{Future Challenges}

We now turn to the main challenges confronting future civil-war research. Our survey of the literature suggests that researchers in this area need to reassess the boundaries between logics and phases of conflict, as well as the geographic and temporal scope of their studies.

\section{Bridging the logics of conflict}

Although our stock-taking exercise has focused on the three main explanatory logics, we by no means want to imply that this classification should constitute the key to future theory-building. If anything, recent research has shown that attempts to isolate one logic from the other is a flawed undertaking (Sambanis 2004b). In reality, all three logics are deeply intertwined. Yet, not unlike IR scholars' habit of classifying variables as "realist" or "liberal," the initial wave of civil-war cross-national studies succumbed to the temptation of running simplistic econometric "horse races" between the main theoretical competitors.

Fortunately, recent advances in civil-war research have started to break down the barriers between the three main logics. For example, models that are 
primarily based on explanations that highlight greed and opportunity need to be complemented with mechanisms that acknowledge the role of emotions, such as anger and resentment, rather than merely focusing on fear in relation to security dilemmas and commitment problems (Costalli and Ruggeri 2015; Petersen 2002). Moreover, there is no reason to treat grievances separately from mobilization, since they constitute primary resources in such processes (McAdam 1982, 33-50) and sometimes help overcome severe collective action problems (Wood 2003).

Likewise, state capacity should not be conceptualized as an exclusively logistical issue without considering the state's cultural penetration, especially where the central government tries to expand its rule into ethnically distinctive regions (e.g., Weiner 1978; Hechter 1975). These perspectives usefully complement Fearon and Laitin's (2003) argument about state weakness by showing how state penetration, especially in the form of internal colonization or aggressive attempts to assimilate, triggers reactive identity formation and collective protest that increase the risk of political violence. While typically dismissed by the economic literature on resources and conflict, grievances and economic inequality fit naturally into such accounts. In fact, recent studies demonstrate that the link between oil and civil war operates primarily through an ethnoregional mechanism (Hunziker and Cederman 2017, cf. Ross 2015).

The usefulness of building bridges between the main logics extends to the grievance literature as well. Although contributors to this perspective have been much less inclined to reject alternative logics than the proponents of greed and 
opportunity explanations (see, e.g., Gurr 1993), there is still a need to integrate both greed and opportunity more deeply in such explanations. For example, clearly far from all elites are idealistically motivated. In fact, greedy and opportunistic politicians sometimes manipulate mass grievances (e.g., Gagnon 2004). Vogt (forthcoming) suggests that in ethnically stratified societies, extreme inequality fuels collective grievances, but also decreases marginalized groups' mobilization capacity and opportunities, resulting in mostly peaceful collective action. Other studies have shown that what started as group mobilization in favor of collective policy aims may turn into a factional contest within the group over private material gains (Cunningham, Bakke, and Seymour 2012).

Furthermore, recent theory building has shown that it is possible to integrate a grievance perspective within a bargaining framework (see, e.g., Wucherpfennig et al. 2012; Roessler 2016).

\section{Bridging the phases of conflict}

In addition to breaking down explanatory silos, future research on civil war should attempt to bridge the phases of conflict. Given the complexity of each phase, it is understandable that so much of the literature has focused on either onset, within-war dynamics, conflict termination, or the post-conflict phase. Yet, recent studies have paved the way for a more integrated perspective.

Rather than treating the outbreak of violent conflict as the analytical starting point, some researchers have attempted to trace the origins of civil war back to an earlier phase of prewar mobilization. Inspired by the social movement literature (McAdam, Tarrow and Tilly 2001), recent contributions adopt an 
explicit focus on non-violent conflict which sheds light on the effectiveness of peaceful protest and accommodative policies that have the potential to prevent the eruption of violence in the first place (Chenoweth and Stephan 2011; White et al. 2015). Similarly, the micro-dynamic literature would benefit from considering cases of repression and one-sided violence before the outbreak of war, rather than focusing primarily on violence during civil war (e.g., Goodwin 2001; Sullivan 2016). As previously discussed, there are also reasons to believe that within-war dynamics are less endogenous than sometimes claimed in the sense that prewar structures constrain identity formation and side shifting (e.g., Staniland 2014). At the same time, studies of the duration of civil war have paid insufficient attention to factors that are truly endogenous to the war itself (Kalyvas and Balcells 2010).

There is also an urgent need to broaden evaluations of peace-inducing factors from focusing merely on measures to terminate war, such as peace agreements, to considering the entire process of conflict, including onset, since the latter holds the key to conflict prevention. For example, while power sharing figures as one of the most important institutional approaches to conflict resolution, such arrangements can also play a crucial role as preventive instruments (e.g., Cederman et al. 2015). Also, whereas the extant literature has established the importance of detailed peace agreements for preventing conflict recurrence, we currently have little knowledge about why some agreements are implemented while others are not. Finally, besides the economic consequences of civil war, we know relatively little about the long-run legacies of political violence, which play a crucial role in triggering recurrent conflict (Walter 2015). 
Finding the right spatiotemporal scope

If civil-war research has been too specific with respect to explanatory logics and conflict phases, much of it has also been too general with respect to both space and time. At least implicitly, most researchers using cross-national research designs with global samples appear to search for the model of civil war. Yet, such research makes very strong assumptions of unit homogeneity (Sambanis 2004b; Tarrow 2007). It is easy to see how ostensibly global explanations of civil war are rooted in particular, traumatic regional experiences. Clearly, the Balkan wars inspired an entire generation of researchers studying "ethnic conflict" and nationalism. In contrast, the economic explanations of civil war that made the field take off in the early 2000s responded to state failure and apparently chaotic civil violence in resource-rich African countries in the late 1990s. Thus, it is possible that researchers give formative historical events too much weight in their effort to build general theory.

Ironically, in the search for more nuanced research designs, the micro-based literature is also exposed to the risks of over-generalization. Although this literature has generated important insights about specific conflicts, it has been much less successful when it comes to aggregating local results up to national, regional, and possibly even global patterns. Articles with titles ending with "evidence from X" presume that they test a general proposition, but very few of them are able to move beyond postulating such claims. In the absence of cogent meta studies, the clever, but idiosyncratic, research designs do not add up to systematic knowledge beyond the cases that provided the evidence in the first 
place. For these reasons, midrange theorizing covering a set of countries in specific world regions while offering a disaggregated perspective on subnational mechanisms serves as a useful complement (e.g., Staniland 2014; Straus 2015).

Similar problems of over-generalizing haunt civil-war studies along the temporal dimension. Studies that take into account geopolitical differences, for example between the Cold War and beyond, belong to the exceptions (e.g., Kalyvas and Balcells 2010). To some extent, the availability of high-quality conflict data also limits the historical depth of the current research agenda to the post-WWII period, but this is starting to change (e.g., Besley and Reynal-Querol 2014). Following the publication of Pinker's (2011) sweeping claims about the decline of violence, a lively debate has emerged concerning long-term conflict trends (Gleditsch et al. 2013), including a possible decline of ethnic civil war (Gurr 2000) although this trend may now be turning (Themnér and Wallensteen 2014).

In the future, conflict scholars will have to steer a middle course between overgeneralized macro models and myopic micro investigations. Such a pragmatic approach would narrow the existing gap between quantitative civil war research and the policy community (Mack 2002). The current tendency to focus on only those research designs that allow for clever inferential solutions could deflect attention from the most important drivers of conflict, especially at the level of national-level dynamics and governmental policies that defy experimental manipulation. Likewise, the quest for exogeneity promises to improve causal identification, but could at the same time shift research away 
from important, fast-changing, and inherently endogenous processes. While clearly useful for both theory and policy within reasonable spatiotemporal bounds (see, e.g., Ward, Greenhill and Bakke 2010), prediction should not be seen as the only empirical criterion that produces reliable knowledge about civil war, especially since the massive complexity of such processes severely limits attempts to forecast future conflict. In cases where the effectiveness of specific conflict resolution methods is associated with high uncertainty, early warning systems may be of limited use even if their predictive performance were to improve considerably (Cederman and Weidmann 2017).

All in all, however, there can be no doubt that civil war research has contributed in a major way to building knowledge about the causes and consequences of the most frequent and damaging type of political violence in the contemporary world. Based on careful empirical research exhibiting increasing methodological sophistication, the literature has built on the pioneering contributions of the early 2000s, and progressed into one of the most active research fields in the social sciences. Hopefully, future research will make even more decisive steps toward preventing and reducing violence in the years to come. 


\section{Notes}

${ }^{1}$ Reflecting common practice, we review analyses of lower-intensity conflicts even though they fall under the customary limit at 1000 battle deaths. For a careful discussion of definitional criteria, see Sambanis (2004a).

${ }^{2}$ Collier, Hoeffler and Rohner (2009) explicitly acknowledge this shift by analyzing civil-war onset as a matter of opportunity rather than as motives.

${ }^{3}$ In response, Fearon (2011) argues that governments' decisions to exclude ethnic groups may be highly endogenous to their conflict proneness. By instrumenting for exclusion in post-colonial states, Wucherpfennig, Hunziker and Cederman (2016) show that previous studies have underestimated, rather than overestimated, the effect of political inequality on the outbreak of civil war. ${ }^{4}$ While the governmental oil curse features very prominently in Fearon and Laitin's (2003) onset account, it all but disappears from Fearon's (2004) explanation of conflict duration.

${ }^{5}$ It should be noted, however, that these "technologies of rebellions" themselves are likely to be endogenous to pre-war conditions.

${ }^{6}$ See the contribution on international peacekeeping operations in this issue. ${ }^{7}$ Although not necessarily subscribing to the greed-based perspective, Doyle and Sambanis' (2006) analysis of United Nations peacekeeping missions also makes a strong case for supporting post-conflict development in order to prevent war recurrence.

8 The same conclusion could be drawn from the greed-as-motivation perspective. If rebels are essentially criminals, repression would be both a legitimate and potentially effective antidote. 


\section{References}

Albertus, Michael, and Oliver Kaplan. 2013. "Land Reform as a

Counterinsurgency Policy." Journal of Conflict Resolution 57 (2):198-231.

Balcells, Laia. 2017. Rivalry and Revenge. New York, NY: Cambridge University Press.

Balcells, Laia, and Stathis N. Kalyvas. 2014. "Does Warfare Matter? Severity, Duration, and Outcomes of Civil Wars." Journal of Conflict Resolution 58 (8):1390-1418.

Bauer, Michal, Christopher Blattman, Julie Chytilová, Joseph Henrich, Edward Miguel, and Tamar Mitts. 2016. "Can War Foster Cooperation?" Journal of Economic Perspectives 30 (3):249-274.

Bayart, Jean-François. 1993. The State in Africa: The Politics of the Belly. London: Longman.

Bellows, John, and Edward Miguel. 2009. "War and Local Collective Action in Sierra Leone." Journal of Public Economics 93 (11-12):1144-1157.

Besley, Timothy, and Marta Reynal-Querol. 2014. "The Legacy of Historical Conflict: Evidence from Africa." American Political Science Review 108 (2):319-336.

Blattman, Christopher. 2009. "From Violence to Voting: War and Political Participation in Uganda." American Political Science Review 103 (2):231247.

Blattman, Christopher, and Jeannie Annan. 2010. "The Consequences of Child Soldiering." Review of Economics and Statistics 92 (4):882-898. 
Blattman, Christopher, and Edward Miguel. 2010. "Civil War." Journal of Economic Literature 48 (1):3-57.

Bormann, Nils-Christian, Lars-Erik Cederman, and Manuel Vogt. 2017. "Language, Religion, and Ethnic Civil War." Journal of Conflict Resolution $61(4): 744-771$.

Brancati, Dawn, and Jack Snyder. 2013. "Time to Kill: The Impact of Election Timing on Postconflict Stability." Journal of Conflict Resolution 57 (5):822853.

Buhaug, Halvard, Scott Gates, and Päivi Lujala. 2009. "Geography, Rebel Capability, and the Duration of Civil Conflict." Journal of Conflict Resolution 53 (4):544-569.

Bunce, Valerie, and Stephen Watts. 2005. "Managing Diversity and Sustaining Democracy: Ethnofederal versus Unitary States in the Postcommunist World." In Sustainable Peace: Power and Democracy after Civil Wars, edited by P. G. Roeder and D. Rothchild. Ithaca, NY: Cornell University Press. 133-158.

Canetti-Nisim, Daphna, Eran Halperin, Keren Sharvit, and Stevan E. Hobfoll. 2009. "A New Stress-Based Model of Political Extremism: Personal Exposure to Terrorism, Psychological Distress, and Exclusionist Political Attitudes." Journal of Conflict Resolution 53 (3):363-389.

Carey, Sabine C., and Neil J. Mitchell. 2017. "Progovernment Militias." Annual Review of Political Science 20:127-147.

Cederman, Lars-Erik, and Luc Girardin. 2007. "Beyond Fractionalization: Mapping Ethnicity onto Nationalist Insurgencies." American Political Science Review 101 (1):173-85. 
Cederman, Lars-Erik, Kristian Skrede Gleditsch, and Halvard Buhaug. 2013. Inequality, Grievances and Civil War. New York: Cambridge Univerisity Press.

Cederman, Lars-Erik, Kristian Skrede Gleditsch, Idean Salehyan, and Julian Wucherpfennig. 2013. "Transborder Ethnic Kin and Civil War." International Organization 67 (2):389-410.

Cederman, Lars-Erik, Simon Hug, Andreas Schädel, and Julian Wucherpfennig. 2015. "Territorial Autonomy in the Shadow of Conflict: Too Little, Too Late?" American Political Science Review 109 (2):354-370.

Cederman, Lars-Erik, and Nils B. Weidmann. 2017. “Predicting Armed Conflict: Time to Adjust Our Expectations?" Science 355 (6324):474-76.

Cederman, Lars-Erik, Nils B. Weidmann, and Kristian Skrede Gleditsch. 2011. "Horizontal Inequalities and Ethno-Nationalist Civil War: A Global Comparison." American Political Science Review 105 (3):478-95.

Cederman, Lars-Erik, Andreas Wimmer, and Brian Min. 2010. "Why Do Ethnic Groups Rebel? New Data and Analysis." World Politics 62 (1):87-119.

Chen, Siyan, Norman V. Loayza, and Marta Reynal-Querol. 2008. "The Aftermath of Civil War." World Bank Economic Review 22 (1):63-85.

Chenoweth, Erica, and Maria J. Stephan. 2011. Why Civil Resinstance Works: The Strategic Logic of Nonviolent Conflict. New York, NY: Columbia University Press.

Collier, Paul, V. L. Elliott, Havard Hegre, Anke Hoeffler, Marta Reynal-Querol, and Nicholas Sambanis. 2003. Breaking the Conflict Trap: Civil War and Development Policy. Washington, DC: The World Bank and Oxford University Press. 
Collier, Paul, and Anke Hoeffler. 2004. "Greed and Grievance in Civil War." Oxford Economic Papers 56 (4):563-595.

Collier, Paul, Anke Hoeffler, and Dominic Rohner. 2009. "Beyond Greed and Grievance: Feasibility and Civil War." Oxford Economic Papers 61 (1):127.

Collier, Paul, Anke Hoeffler, and Måns Söderbom. 2004. "On the Duration of Civil War." Journal of Peace Research 41 (3):253-273.

Collier, Paul, Anke Hoeffler, and Måns Söderbom. 2008. "Post-Conflict Risks." Journal of Peace Research 45 (4):461-478.

Costalli, Stefano, and Andrea Ruggeri. 2015. "Indignation, Ideologies, and Armed Mobilization: Civil War in Italy, 1943-45." International Security 40 (2):119-157.

Cramer, Christopher. 2003. "Does Inequality Cause Conflict?". Journal of International Development 15 (4):397-412.

Cunningham, David E. 2006. "Veto Players and Civil War Duration." American Journal of Political Science 50 (4):875-892.

Cunningham, David E., Kristian S. Gleditsch, and Idean Salehyan. 2009. "It Takes Two: A Dyadic Analysis of Civil War Duration and Outcome." Journal of Conflict Resolution 53 (4):570-597.

Cunningham, Kathleen Gallagher. 2013. "Actor Fragmentation and Civil War Bargaining: How Internal Divisions Generate Civil Conflict." American Journal of Political Science 57 (3):659-672.

Cunningham, Kathleen Gallagher, Kristin M. Bakke, and Lee J. M. Seymour. 2012. "Shirts Today, Skins Tomorrow: Dual Contests and the Effects of 
Fragmentation in Self-Determination Disputes." Journal of Conflict Resolution 56 (1):67-93.

Diamond, Larry. 2006. "Promoting Democracy in Post-Conflict and Failed States: Lessons and Challenges." Taiwan Journal of Democracy 2 (2):93-116.

Doyle, Michael W., and Nicholas Sambanis. 2006. Making War and Building Peace: United Nations Peace Operations. Princeton, NJ: Princeton University Press.

Fearon, James D. 2003. "Ethnic and Cultural Diversity by Country." Journal of Economic Growth 8 (2):195-222.

Fearon, James D. 2011. "Governance and Civil War Onset." World Development Report: 6406082-1283882418764.

Fearon, James D. 2004. "Why Do Some Civil Wars Last So Much Longer than Others?" Journal of Peace Research 41 (3):275-301.

Fearon, James D., and David D. Laitin. 2003. "Ethnicity, Insurgency, and Civil War." The American Political Science Review 97 (1):75-90.

Fjelde, Hanne, and Lisa Hultman. 2014. "Weakening the Enemy: A Disaggregated Study of Violence against Civilians in Africa." Journal of Conflict Resolution 58 (7):1230-1257.

Forsberg, Erika. 2016. "Transnational Dimensions of Civil Wars: Clustering, Contagion, and Connectedness." In What Do We Know About Civil Wars?, eds. T. David Mason and Sara McLaughlin Mitchell. Lanham, MD: Rowman \& Littlefield.

Gagnon, Valère Philip Jr. 2004. The Myth of Ethnic War: Serbia and Croatia in the 1990s. Ithaca, NY: Cornell University Press. 
Gates, Scott. 2002. "Recruitment and Allegiance: The Microfoundations of Rebellion." Journal of Conflict Resolution 46 (1):111-30.

Gellner, Ernest. 1983. Nations and Nationalism. Oxford: Blackwell Publishing. Gleditsch, Kristian Skrede. 2007. "Transnational Dimensions of Civil War." Journal of Peace Research 44 (3):293-309.

Gleditsch, Nils Petter, Peter Wallensteen, Mikael Eriksson, Margareta Sollenberg, and Håvard Strand. 2002. "Armed Conflict 1946-2001: A New Dataset." Journal of Peace Research 39 (5):615-637.

Gleditsch, Nils Petter, Steven Pinker, Bradley A. Thayer, Jack S. Levy, and William R. Thompson. 2013. "The Forum: The Decline of War." International Studies Review 15 (3):396-419.

Goodwin, Jeff. 2001. No Other Way Out: States an Revolutionary Movements, 1945-1991. Cambridge: Cambridge University Press.

Grossman, Guy, Devorah Manekin, and Dan Miodownik. 2015. "The Political Legacies of Combat: Attitudes Toward War and Peace Among Israeli ExCombatants." International Organization 69 (4):981-1009.

Gurr, Ted Robert. 1970. Why Men Rebel. Princeton: Princeton University Press. Gurr, Ted Robert. 1993. Minorities at Risk: A Global View of Ethnopolitical Conflicts. Washington, DC: United States Institute of Peace Press. Gurr, Ted Robert. 2000. "Ethnic Warfare on the Wane." Foreign Affairs 79 (3):5265.

Gurr, Ted Robert, and James R. Scarritt. 1989. "Minorities Rights at Risk: A Global Survey." Human Rights Quarterly 11 (3):375-405. 
Gutiérrez Sanín, Francisco, and Elisabeth Jean Wood. 2014. "Ideology in Civil War: Instrumental Adoption and Beyond." Journal of Peace Research 51 (2):213-226.

Hartzell, Caroline A., and Matthew Hoddie. 2003. "Institutionalizing Peace: Power Sharing and Post-Civil War Conflict Management." American Journal of Political Science 47 (2):318-332.

Hechter, Michael. 1975. Internal Colonialism: The Celtic Fringe in British National Development, 1536-1966. Berkeley: University of California Press.

Hegre, Håvard, Tanja Ellingsen, Scott Gates, and Nils Petter Gleditsch. 2001. "Toward a Democratic Civil Peace? Democracy, Political Change, and Civil War, 1816-1992." American Political Science Review 95 (1):33-48.

Hegre, Håvard, and Nicholas Sambanis. 2006. "Sensitivity Analysis of Empirical Results on Civil War Onset." Journal of Conflict Resolution 50 (4):508-535. Hendrix, Cullen S. 2010. "Measuring State Capacity: Theoretical and Empirical Implications for the Study of Civil Conflict." Journal of Peace Research 47 (3):273-285.

Hug, Simon. 2013. "The Use and Misuse of the `Minorities at Risk' Project." Annual Review of Political Science 16: 191-208.

Humphreys, Macartan, and Jeremy M. Weinstein. 2006. "Handling and Manhandling Civilians in Civil War." American Political Science Review 100 (3):429-447.

Humphreys, Macartan, and Jeremy M. Weinstein. 2008. "Who Fights? The Determinants of Participation in CivilWar." American Journal of Political Science 52 (2):436-455. 
Huntington, Samuel P. 1996. The Clash of Civilizations and the Remaking of World Order. New York: Simon \& Shuster.

Hunziker, Philipp, and Lars-Erik Cederman. 2017. "No Extraction Without Representation: The Ethno-regional Oil Curse and Secessionist Conflict." Journal of Peace Research 54 (3):365-381.

Kalyvas, Stathis N. 2006. The Logic of Violence in Civil War. Cambridge: Cambridge University press.

Kalyvas, Stathis N. 2007. "Civil Wars." In The Oxford Handbook of Comparative Politics, eds. Carles Boix and Susan C. Stokes. Oxford: Oxford University Press.

Kalyvas, Stathis N., and Laia Balcells. 2010. "International System and Technologies of Rebellion: How the End of the Cold War Shaped Internal Conflict." American Political Science Review 104 (3):415-29.

Kalyvas, Stathis N., and Matthew Adam Kocher. 2007. "How 'Free' Is Free Riding in Civil Wars? Violence, Insurgency, and the Collective Action Problem." World Politics 59 (2):177-216.

Kaplan, Robert D. 1994. "The Coming Anarchy." Atlantic Monthly 273: 44-76.

Kaplan, Oliver, and Enzo Nussio. Forthcoming. "Explaining Recidivism of Excombatants in Colombia." Journal of Conflict Resolution. DOI: $10.1177 / 0022002716644326$.

Kocher, Matthew Adam, Thomas B. Pepinsky, and Stathis N. Kalyvas. 2011. "Aerial Bombing and Counterinsurgency in the Vietnam War." American Journal of Political Science 55 (2):201-218.

Levy, Jack S. 1989. "The Causes of War: A Review of Theories and Evidence." In Behavior, Society, and Nuclear War, eds. Philip E. Tetlock, Jo L. Husbands, 
Robert Jervis, Paul C. Stern and Charles Tilly. Oxford: Oxford University Press. 209-333.

Lujala, Päivi. 2010. "The Spoils of Nature: Armed Civil Conflict and Rebel Access to Natural Resources." Journal of Peace Research 47 (1):15-28.

Lyall, Jason. 2009. "Does Indiscriminate Violence Incite Insurgent Attacks? Evidence from Chechnya." Journal of Conflict Resolution 53 (3):331-362. Mack, Andrew. 2002. "Civil War: Academic Research and the Policy Community." Journal of Peace Research 39 (5):515-525.

Mattes, Michaela, and Burcu Savun. 2010. "Information, Agreement Design, and the Durability of Civil War Settlement." American Journal of Political Science 54 (2):511-524.

McAdam, Doug. 1982. Political Process and the Development of Black Insurgency, 1930-1970. Chicago, IL: University of Chicago Press.

McAdam, Doug, Sidney Tarrow, and Chalres Tilly. 2001. Dynamics of Contention. Cambridge: Cambridge University Press.

McGarry, John, and Brendan O'Leary. 2009. "Must Pluri-national Federations Fail?" Ethnopolitics 8 (1):5-25.

Metternich, Nils W., Shahryar Minhas, and Michael D. Ward. Forthcoming. "Firewall? or Wall on Fire? A Unified Framework of Conflict Contagion and the Role of Ethnic Exclusion." Journal of Conflict Resolution. DOI: $10.1177 / 0022002715603452$.

Miguel, Edward, and Gérard Roland. 2011. "The Long-run Impact of Bombing Vietnam." Journal of Development Economics 96 (1):1-15.

Murdoch, James C., and Todd Sandler. 2002. "Economic Growth, Civil Wars, and Spatial Spillovers." Journal of Conflict Resolution 46 (1):91-110. 
Østby, Gudrun. 2008. "Polarization, Horizontal Inequalities and Violent Civil Conflict." Journal of Peace Research 45 (2):143-162.

Paine, Jack. 2016. "Rethinking the 'Resource Curse': How Oil Wealth Prevents Center-Seeking Civil Wars." International Organization 70 (4):727-761.

Paris, Roland. 2004. At War's End: Building Peace After Civil Conflict. New York, NY: Cambridge University Press.

Petersen, Roger D. 2002. Understanding Ethnic Violence: Fear, Hatred, and Resentment in Twentieth-Century Eastern Europe. Cambridge: Cambridge University Press.

Pinker, Steven. 2011. The Better Angels of Our Nature: Why Violence Has Declined. New York: Viking.

Posen, Barry R. 1993. "The Security Dilemma and Ethnic Conflict." Survival 35 (1):27-47.

Reno, William. 1998. Warlord Politics and African States. Boulder, CO: Lynne Rienner.

Roeder, Philip G. 2009. "Ethnofederalism and the Mismanagement of Conflicting Nationalisms." Regional \& Federal Studies 19 (2):203-219.

Roessler, Philip. 2011. "The Enemy Within: Personal Rule, Coups, and Civil War in Africa." World Politics 63 (2):300-346.

Roessler, Philip. 2016. Ethnic Politics and State Power in Africa: The Logic of the Coup-Civil War Trap. New York: Cambridge University Press.

Ross, Michael L. 2015. "What Have We Learned About the Resource Curse?". Annual Review of Political Science 18: 239-59. 
Saideman, Stephen M., and Erin K. Jenne. 2009. "The International Relations of Ethnic Conflict." In Handbook of War Studies Iii: The Intrastate Dimension, ed. Manus I. Midlarsky. Ann Arbor: University of Michigan Press.

Salehyan, Idean, and Kristian Skrede Gleditsch. 2006. "Refugees and the Spread of Civil War." International Organization 60 (2):335-366.

Sambanis, Nicholas. 2002. "A Review of Recent Advances and Future Directions in the Quantitative Literature on Civil War." Defence and Peace Economics 13 (3):215-243.

Sambanis, Nicholas. 2004a. "What Is Civil War? Conceptual and Empirical Complexities of an Operational Definition." Journal of Conflict Resolution $48(6): 814-858$.

Sambanis, Nicholas. 2004b. "Using Case Studies to Expand Economic Models of Civil War." Perspectives on Politics 2 (2):259-279.

Sambanis, Nicholas, and Jonah Schulhofer-Wohl. 2009. "What's in a Line? Is Partition a Solution to Civil War?" International Security 34 (2):82-118.

Samii, Cyrus. 2013. "Perils or Promise of Ethnic Integration? Evidence from a Hard Case in Burundi." American Political Science Review 107 (3):558573.

Schutte, Sebastian. Forthcoming. "Violence and Civilian Loyalties: Evidence from Afghanistan." Journal of Conflict Resolution. DOI: $10.1177 / 0022002715626249$.

Scott, James C. 1976. The Moral Economy of the Peasant: Rebellion and Subsistence in Southeast Asia. New Haven: Yale University Press. Skocpol, Theda. 1979. States and Social Revolutions: A Comparative Analysis of France, Russia, and China. Cambridge: Cambridge University Press. 
Staniland, Paul. 2014. Networks of Rebellion: Explaining Insurgent Cohesion and Collapse. Ithaca, NY: Cornell University Press.

Stewart, Frances, ed. 2008. Horizontal Inequalities and Conflict: Understanding Group Violence in Multiethnic Societies. Houndmills: Palgrave Macmillan.

Straus, Scott. 2015. Making and Unmaking Nations: War, Leadership, and Genocide in Modern Africa. Ithaca, NY: Cornell University Press.

Sullivan, Christopher M. 2016. "Political Repression and the Destruction of Dissident Organizations." World Politics 68 (4): 645-676.

Tarrow, Sidney. 2007. "Inside Insurgencies: Politics and Violence in an Age of Civil War." Perspectives on Politics 5 (3):587-600.

Themnér, Lotta, and Peter Wallensteen. 2014. "Armed Conflicts, 1946-2013." Journal of Peace Research 51 (4):541-554.

Thomas, Jakana. 2014. "Rewarding Bad Behavior: How Governments Respond to Terrorism in Civil War." American Journal of Political Science 58 (4):804818.

Tilly, Charles. 1978. From Mobilization to Revolution. New York: McGraw-Hill.

Tollefsen, Andreas Forø, and Halvard Buhaug. 2015. "Insurgency and Inaccessibility." International Studies Review 17 (1):6-25.

Tull, Denis M., and Andreas Mehler. 2005. "The Hidden Costs of Power-Sharing: Reproducing Insurgent Violence in Africa." African Affairs 104 (416):375398.

Ugarriza, Juan E., and Matthew J. Craig. 2013. "The Relevance of Ideology to Contemporary Armed Conflicts." Journal of Conflict Resolution 57 (3):445477. 
Valentino, Benjamin A. 2014. "Why We Kill: The Political Science of Political Violence against Civilians." Annual Review of Political Science 17: 89-103. Valentino, Benjamin, Paul Huth, and Dylan Balch-Lindsay. 2004. "“Draining the Sea": Mass Killing and Guerrilla Warfare." International Organization 58 (2):375-407.

Vogt, Manuel. Forthcoming. "Ethnic Stratification and the Equilibrium of Inequality: Ethnic Conflict in Post-colonial States." International Organization.

Vreeland, James Raymond. 2008. "The Effect of Political Regime on Civil War : Unpacking Anocracy." Journal of Conflict Resolution 52 (3):401-425.

Walter, Barbara F. 1997. "The Critical Barrier to Civil War Settlement." International Organization 51 (3):335-364.

Walter, Barbara F. 2015. "Why Bad Governance Leads to Repeat Civil War." Journal of Conflict Resolution 59 (7):1242-1272.

Ward, Michael D., Brian Greenhill, and Kristin Bakke. 2010. "The Perils of Policy by P-Value: Predicting Civil Conflicts." Journal of Peace Research 47 $(4): 363-375$.

Weidmann, Nils B. 2011. "Violence 'from above' or 'from Below"'? The Role of Ethnicity in Bosnia's Civil War." Journal of Politics 73 (4):1178-1190.

Weiner, Myron. 1978. Sons of the Soil: Migration and Ethnic Conflict in India. Princeton, NJ: Princeton University Press.

Weinstein, Jeremy. 2007. Inside Rebellion: The Politics of Insurgent Violence. Cambridge: Cambridge University Press.

White, Peter B., Dragana Vidovic, Belén González, Kristian Skrede Gleditsch, and David E. Cunningham. 2015. "Nonviolence as a Weapon of the 
Resourceful: From Claims to Tactics in Mobilization." Mobilization: An International Journal 20 (4):471-491.

Wilkinson, Steven. 2015. Army and Nation: The Military and Indian Democracy Since Independence. Cambridge, MA: Harvard University Press.

Wood, Elisabeth Jean. 2003. Insurgent Collective Action and Civil War in El Salvador. Cambridge: Cambridge Unversity Press.

Wucherpfennig, Julian, Philipp Hunziker, and Lars-Erik Cederman. 2016. "Who Inherits the State? Colonial Rule and Post-Colonial Conflict." American Journal of Political Science 60 (4):882-898..

Wucherpfennig, Julian, Nils Metternich, Lars-Erik Cederman, and Kristian S. Gleditsch. 2012. "Ethnicity, the State, and the Duration of Civil Wars." World Politics 64 (1):79-115. 